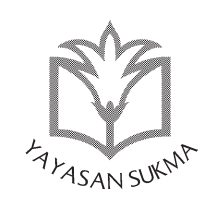

SUKMA: JURNAL PENDIDIKAN

ISSN: 2548-5105

Volume 1 Issue 1, Jan-Jun 2017, hlm. 57-92

\title{
MENYEMAI PERILAKU PROSOSIAL DI SEKOLAH
}

\section{Khoiruddin Bashori}

Universitas Ahmad Dahlan Yogyakarta, Indonesia email: khoiruddinbashori@gmail.com

\begin{abstract}
Abstrak
Perilaku prososial adalah perilaku memberikan manfaat kepada orang lain dengan membantu meringankan beban fisik atau psikologinya, yang dilakukan secara sukarela. Bentuknya dapat beraneka ragam. Perkembangan perilaku prososial berkaitan dengan penalaran moral siswa. Konsep kunci untuk memahami perkembangan moral adalah internalisasi, yaitu perubahan perkembangan perilaku yang pada mulanya dikendalikan secara eksternal menuju perilaku yang dikendalikan secara internal. Sejak dirni siswa perlu dibiasakan dengan nilai-nilai prososial. Dengan kuatnya nilai-nilai internal anak yang dibawa siswa dari sekolah diharapkan anak tidak terlalu
\end{abstract}


tergantung pada situasi-situasi eksternal, dan lebih yakin dengan standar-standar internal perilakunya sendiri. Di sekolah perlu dikurangi ambiguitas lingkungan dan diajarkan perilaku bertanggung jawab. Siswa perlu diberi kesempatan yang lebih luas untuk berinteraksi secara positif. Hubungan sebaya yang positif memberikan kesempatan bagi siswa untuk belajar dan berlatih keterampilan prososial. Interaksi kolaboratif dengan teman sebaya juga diyakini dapat memotivasi pengembangan keterampilan kognitif yang mendukung terbentuknya perilaku prososial. Di samping itu, kedekatan hubungan guru dengan siswa juga memiliki peran penting dalam internalisasi nilainilai prososial. Dalam konteks pembelajaran, model instruksional kooperatif dan kolaboratif terbukti lebih dapat menumbuhkan perilaku menolong.

Kata Kunci: perilaku prososial; perkembangan moral; pembelajaran kolaboratif; kedekatan guru-siswa

\section{Pendahuluan}

Kini genap 10 tahun peristiwa gempa bumi yang terjadi pada tanggal 27 Mei 2006 di Yogyakarta dan sekitarnya. Pada saat peristiwa tersebut berlangsung, masyarakat di Kota Yogyakarta dan sekitarnya yang merasakan langsung getaran tersebut berhamburan menyelamatkan diri semampunya untuk menghindari reruntuhan bangunan. Dalam kondisi ini para korban berada dalam dua pilihan yang sulit, menyelamatkan diri sendiri dan atau membantu menyelamatkan orang lain yang tertimpa bangunan. Banyak di antara para korban selamat mengaku tak sempat untuk menyelamatkan sanak saudaranya karena sibuk menyelamatkan diri dan ada juga yang selamat dengan tergopohgopoh menyelamatkan sanak saudaranya ataupun orang lain yang sama sekali belum di kenal sebelumnya. Dari peristiwa tersebut dapat dipelajari secara mendalam tentang apa yang membuat 
beberapa orang membantu dan beberapa orang lainnya tidak? Mengapa seseorang tak membantu sanak saudaranya, sementara ada orang yang membantu orang lain yang bahkan belum dikenalnya sama sekali?

Peristiwa lain terjadi di Kalimantan. Kompas melaporkan (27/11/2015) Anik, seorang bidan, meninggal dunia seusai membantu proses melahirkan dua pasien. Meski agak kurang sehat, Anik memenuhi panggilan salah satu pasiennya yang tinggal di Dusun Betung, Desa Tembawang Bale, untuk membantu proses melahirkan. Hebatnya, Anik menyanggupi permintaan tersebut meski dalam kondisi tengah hamil. Dengan diantar suami menggunakan mobil pribadi, Anik datang ke rumah pasien. Proses melahirkan berlangsung hingga sekitar pukul 19.00 WIB. Tak berselang lama, datang lagi panggilan untuk membantu proses melahirkan di dusun yang sama. Walau dalam kondisi yang saat itu sedang lelah seusai menolong persalinan pasien sebelumnya, bidan Anik kembali menyanggupi menolong persalinan. Sekitar pukul 20.00 WIB, Anik diantar suami dan anaknya menuju rumah pasien yang kedua. Proses melahirkan berlangsung hingga pukul 00.30 WIB dini hari. Karena kelelahan, Anik merasakan ada sesuatu yang tidak semestinya pada kandungannya. Dari hasil pemeriksaan, bayi dalam kandungan Anik dinyatakan sudah meninggal dunia. Tim medis pun kemudian melakukan tindakan dengan melakukan operasi untuk mengeluarkan bayi tersebut. Dalam penanganan, terjadi pendarahan hebat lantaran ada kelainan pada plasenta sehingga Anik membutuhkan darah untuk memulihkan kondisinya. Namun, sayang, upaya terebut gagal hingga akhirnya Anik mengembuskan napas terakhirnya.

\section{Pengertian Perilaku Prososial}

Psikolog sosial berpendapat, pada dasarnya setiap perilaku berorientasi pada tujuan. Ini berarti, pada umumnya suatu perilaku dimotivasi oleh suatu keinginan untuk mencapai tujuan tertentu, meskipun tidak selalu secara sadar pelakunya menge- 


\section{Khoiruddin Bashori}

taui tujuannya secara spesifik. Prososial sendiri dapat diartikan sebagai suatu tindakan heroik dengan tujuan untuk menolong orang lain (Passer \& Smith, 2007). Oleh karena itu, perilaku prososial dipahami sebagai suatu tindakan menolong yang menguntungkan orang lain tanpa harus menyediakan suatu keuntungan langsung pada orang yang melakukan tindakan tersebut. Terdapat semacam niatan tulus dalam perilaku menolong ini. Dengan demikian, perilaku menolong yang bersifat transaksional tidak dapat dimasukkan ke dalam perilaku prososial. Misalnya, perilau menolong pendukung partai politik tertentu yang beramai-ramai menjadi relawan dengan kaos dan bendera partainya untuk "membantu" korban bencana banjir, tanah longsor atau letusan gunung berapi dengan maksud "kampanye" terselubung.

Dalam perilaku prososial terdapat maksud untuk mengubah keadaan fisik atau psikologis penerima bantuan dari kurang baik menjadi lebih baik. Berbagai upaya yang dilakukan untuk meringankan beban, memperbaiki keadaan orang lain yang membutuhkan pertolongan dapat digolongkan sebagai perilaku prososial. Dapat dikatakan, tingkah laku prososial menimbulkan konsekuensi positif bagi kesejahteraan fisik maupun psikis orang lain yang dibantu. Bentuk dari perilaku prososial ini dapat beraneka ragam, mulai dari menyumbang, mendampingi, memperhatikan kesejahteraan orang lain dengan berbagai langkah kedermawanan, mempererat persahabatan, kerjasama yang saling menguatkan, menolong korban, menyelamatkan orang lain tanpa diminta, sampai mengorbankan diri untuk orang lain. Perilaku prososial juga mencakup tindakan yang dilakukan untuk memberikan keuntungan bagi orang lain, seperti berbagi, menghibur, memuji prestasi orang lain untuk menyenangnan hatinya, sampai menolong orang lain dalam mencapai tujuannya. Dengan kata lain, perilaku prososial bertujuan untuk membantu meningkatkan kebahagiaan orang lain, dikarenakan seseorang yang melakukan tindakan prososial turut mensejahterakan kehidupan penerima bantuan.

Orang sering mempertukarkan istilah prososial dengan altruism. Memang istilah altruisme sering digunakan secara ber- 
gantian dengan prososial, tapi sebenarnya altruisme merupakan hasrat untuk menolong orang lain tanpa memikirkan kepentingan sendiri, melainkan untuk kebaikan orang lain (Baron \& Byrne, 2000). Altruisme adalah tindakan sukarela yang dilakukan seseorang atau sekelompok orang untuk menolong orang lain tanpa mengharapakan imbalan apapun, kecuali mungkin perasaan puas telah melakukan kebaikan. Namun menurut Faturochman (2006), pengertian perilaku prososial sedikit berbeda dengan altruisme, karena lebih menekankan pada adanya keuntungan pada pihak yang diberi pertolongan. Dengan demikian, perilaku prososial tidak lain adalah perilaku memberikan manfaat kepada orang lain dengan membantu meringankan beban fisik atau psikologinya, yang dilakukan secara sukarela.

\section{Perkembangan Moral dan Perilaku Prososial}

Bagaimana kita dapat mengenal nilai-nilai moral, baik dan buruk? Apakah dengan sendirinya atau melalui proses belajar sosial yang panjang? Bagaimana seseorang memilih untuk melakukan perilaku menolong orang lain yang dianggapnya bermoral, dan meninggalkan perilaku lain yang dianggapnya bertentangan dengan kaidah-kaidah moral? Perilaku prososial, dalam realitas sejarah selalu bervariasi dari satu individu ke individu lainya, mungkin sekali sebagai akibat dari perbedaan yang dimiliki masing-masing dalam mengembangkan sistem nilai internalnya. Sungguh beruntung pribadi yang tumbuh dalam lingkungan keluarga, sekolah dan masyarakat yang menjunjung tinggi nilai-nilai moral prososial. Pada sisi lain, terdapat pula pribadi yang berada pada situasi keluarga, sekolah, dan komunitas yang buruk dalam pengembangan nilai-nilai, karakter dan moralitas otentik. Meminjam perspektif Piaget, moralitas seseorang berkembang melalui tiga tahapan: amoral, heteronomous, dan autonomous. Meskipun pandangan demikian dianggap oleh Kohlberg sebagai terlalu sederhana, dan pada akhirnya dia elaborasi dan lengkapi dalam penelitian disertasinya di Universitas Chicago, namun dalam melihat perkembangan moral 
anak, Kohlberg masih sangat dipengaruhi oleh pemikiran Piaget. Terutama oleh dua gagasan dasarnya, yaitu mengenai 'struktur' mental kognitif dan mengenai 'tahap' (Durkin, 1995).

Menurut Piaget anak ibarat pemikir yang dapat membangun dan menyusun dunia hidup serta arti mengenai sejumlah kategori melalui tahap-tahap tertentu. Dalam penelitian Kohlberg mengenai dilema moral yang disodorkan kepada anak, tampak terdapat pikiran dengan struktur kognitif tertentu. Setiap kali anak bereaksi terhadap suatu dilema moral, pastilah didasarkan pada suatu pola operasi mental yang tersusun secara struktural. Dan berkat struktur kognitif khasnya ini pula anak kemudian memilih logika internalnya sendiri yang berbeda dari logika orang dewasa. Adapun konsep 'tahap' yang dimaksudkan oleh Kohlberg adalah setiap konstruksi mental kognitif yang secara kualitatif bersifat khas. Pada kenyataannya, dari berbagai penelitian yang dilakukan, pada akhirnya dapat disimpulkan, terdapat suatu ukuran tahap yang tetap dan tak dapat dibalik yang harus dilewati setiap orang sepanjang rentang kehidupannya. Konsep kunci untuk memahami perkembangan moral menurut Kohlberg adalah internalisasi, yaitu perubahan perkembangan perilaku yang pada mulanya dikendalikan secara eksternal menuju perilaku yang dikendalikan secara internal. (Durkin, 1995).

Menurut Kohlberg (1976; 1981; Kurtines \& Gerwitz, 1984) perkembangan moral seseorang berlangsung menurut tahapan sebagai berikut:

\section{Tingkat Pra-konvensional (Pre-Conventional)}

Tingkat ini merupakan tahap paling awal dalam perkembangan penalaran moral. Biasanya tahap ini terjadi pada anak usia empat sampai sepuluh tahun, namun di lapangan tidak sedikit orang dewasa yang perkembangan penalaran moralnya juga masih berada pada tahap ini. Orang melihat perilaku baik dan buruk dari hadiah atau hukuman yang diberikan dari luar. Pada tahap ini, moralitas dari suatu tindakan didasarkan pada konsekuensi langsungnya. Perilaku baik mendapatkan hadiah, 
perilaku buruk mendapatkan hukuman. Pada tahap ini anak telah memahami aturan-aturan dari lingkungan dan ungkapanungkapan budaya mengenai baik dan buruk, benar dan salah, namun ditafsirkannya dari akibat fisik atau kenikmatan perbuatan yang dirasakannya. Misalnya dalam bentuk keuntungan material atau pertukaran kebaikan. Dalam hal ini, anak juga akan lebih mudah mengenal nilai baik buruk jika orang dewasa di sekitarnya konsisten dalam memberikan hadiah atau hukuman terhadap perilaku tertentu yang ditunjukkan oleh anak. Tingkat ini dibedakan menjadi dua tahap:

\section{Tahap 1: Orientasi kepatuhan dan hukuman (Obedience and punishment orientation)}

Pada tahap ini yang menentukan baik-buruknya suatu perbuatan adalah akibat-akibat fisiknya, tanpa menghiraukan arti dan nilai luhur dari perilaku tersebut. Penalaran moral didasarkan atas hukuman, dan anak taat karena orang dewasa menuntut mereka untuk itu. Manakala tidak mentaati perintah orang dewasa di sekitarnya, anak akan mendapatkan hukuman. Semakin keras human yang diterima anak akan dipahami sebagai kesalahan yang semakin besar. Karenanya, anak menghindar dari hukuman dan tunduk pada kekuasaan semata-mata karena otoritas eksternal, tanpa mempersoalkan apakah perilaku tersebut memiliki bernilai penting bagi dirinya sendiri atau karena rasa hormat terhadap tatanan etik tertentu.

\section{Tahap 2: Orientasi Minat Pribadi (Self-interest orientation)}

Tahap kedua ini agak berbeda dengan tahap sebelumnya yang lebih menekankan pada peran hukuman dari luar bagi perkembangan penalaran moral anak, pada tahap ini perbuatan yang dianggap benar oleh anak adalah perbuatan yang merupakan cara atau alat untuk memuaskan kebutuhannya sendiri. Pusat orientasi adalah dirinya sendiri. Suatu perbuatan dianggap baik bila sesuai dengan kepentingannya sendiri. Hubungan antar manusia dipandang seperti hubungan dagang, bersifat trans- 
aksional. Di sini yang penting adalah kewajaran tindakan yang bersifat timbal balik, dengan pembagian sama rata. Anak akan membantu temannya apabila temannya juga bersedia membantunya. Dalam hal ini perilaku moral masih ditafsirkan anak secara fisik dan pragmatis. Manfaatpun dipahami individu masih dalam bentuk fisik yang kasat mata, dan segera. Moralitas timbal balik di sini maksudnya adalah kalau seseorang berbuat baik kepadanya, sudah sewajarnya jika nanti ia ganti berbuat baik kepada sahabatnya itu. Tindakan demikian dilakukan semata-mata karena keharusan ganti membalas, membalas kebaikan yang pernah diterimanya, bukan karena loyalitas, wujud ungkapan rasa terima kasih atau dorongan nilai keadilan universal.

\section{Tingkat Konvensional (Conventional)}

Level ini disebut tingkat konvensional karena perkembangan penalaran moral seseorang lebih mengikuti konvensi, menurut pada harapan keluarga, kelompok atau komunitas. Tingkat konvensional umumnya ada pada remaja atau orang dewasa. Di tahap ini orang menilai moralitas suatu tindakan dengan membandingkannya dengan pandangan dan harapan masyarakat. Harapan-harapan itu dipandangnya sebagai hal yang bernilai bagi dirinya sendiri, dan tidak lagi terlalu mengindahkan akibat yang segera dan nyata. Mereka ini sudah mulai menginternalisasi standar-standar moralitas dari orang dewasa lain yang dijadikanya model. Sikapnya bukan saja konformis terhadap harapan pribadi dan tata tertib sosial, melainkan juga loyal terhadapnya dan secara aktif mempertahankan, mendukung dan membenarkan seluruh tata tertib itu serta mengidentifikasikan diri dengan orang atau kelompok yang diteladani. Tingkat ini dibagi menjadi dua tahap:

\section{Tahap 3: Orientasi kesepakatan antar pribadi dan konformitas (Interpersonal accord and conformity)}

Pada tahap ini, pusat orientasi bagi perilaku moral telah bergeser keluar, tidak lagi berpusat pada ego sendiri. Perilaku 
Menyemai Perilaku Prososial di Sekolah

dianggap baik tidak lagi berupa perilaku yang mendatangkan kesenangan bagi individu, akan tetapi yang menyenangkan, membantu dan yang disetujui oleh orang lain. Dengan kata lain pada tahap ini anak akan menilai baik apa yang menyenangkan dan disetujui orang lain, dan buruk apa yang ditolak orang lain. Itulah sebabnya mengapa bagi remaja salah satu hal yang dianggap paling menyakitkan apabila mendapatkan penolakan, mesara tidak diterima oleh kelompaknya. Jika seperti itu situasinya, anak dapat merasa kesepian di tengah keramaian. Ada semacam perasaan teralienasi. Oleh karena itu pada level ini terdapat banyak konformitas terhadap gambaran stereotip mengenai apa itu perilaku mayoritas. Anak juga mulai menilai perilaku berdasarkan niatnya. Pada tahap ini 'maksud baik' menjadi penting.

\section{Tahap 4: Orientasi otoritas dan pemeliharaan aturan sosial (Authority and social-order maintaining orientation)}

Pada tahap ini, penalaran moral didasarkan atas pemahaman akan aturan sosial, hukum-hukum, dan ketertiban masyarakat. Di sini mematuhi hukum, keputusan, dan konvensi sosial dianggap sangat penting karena berguna dalam memelihara fungsi sosial masyarakat. Penalaran moral dalam tahap empat bukan lagi sekedar kebutuhan akan penerimaan sosial seperti dalam tahap tiga, akan tetapi kebutuhan masyarakat harus lebih diutamakan. Idealisme menentukan apa yang benar dan apa yang salah. Bagi individu yang memiliki idealisme, menjaga ketertiban dan keharmonisan masyarat menjadi pertimbnagan moral yang sangat penting. Dalam konteks ini, mulai ada semacam kesadaran untuk dengan lebih bersungguh-sungguh mematuhi aturan hukum dan norma-norma sosial yang berlaku. Di sini yang diutamakan adalah sistem sosial dan hati nurani. Mengerjakan sesuatu yang benar pada tahap ini berarti mengerjakan tugas kemasyarakatan dan mendukung tata aturan sosial masyarakat. Tanggung jawab dan komitmen seseorang diekspresikan dengan menjaga aturan sosial dan menghormati diri sendiri. Kalau bukan kita, siapa 
lagi yang akan menjaga ketertiban sosial? Di tahap ini tumbuh semacam kesadaran akan kewajiban menjaga ketertiban sosial, dalam arti ingin mempertahankan otoritas dan aturan-aturan yang ada, karena hal itu memang dianggapnya berharga. Orang dianggap salah secara moral apabila melanggar hukum. Menurut teori ini, jika seseorang abai terhadap otoritas dan tata aturan hukum yang berlaku di masyarakat, dapat dipastikan bahwa perkembangan moralnya belum mencapai tahap 4 .

\section{Tingkat Pasca-Konvensional (Post-Conventional)}

Pada tingkat ini orang berusaha dengan sungguh-sungguh untuk merumuskan nilai-nilai dan prinsip moral yang memiliki keabsahan dan dapat diterapkan dalam kehidupan, terlepas dari otoritas kelompok atau orang yang berpegang pada prinsip-prinsip itu. Individu juga sudah mulai terlepas pula dari identifikasi atau imitasi terhadap kelompok. Di sini proses internalisasi sudah tuntas, orang telah dapat menentukan keputusan moral secara mandiri, berdasarkan kayakinan dan prinsip-prinsip hidupnya sendiri. Ada dua tahap pada tingkat ini:

\section{Tahap 5: Orientasi kontrak sosial (Social contract orientation)}

Tahap ini kontrak sosial dan hak individual merupakan pertimbangan utama. Oleh karena itu, yang dianggap benar di sini adalah yang mendukung hak-hak dan nilai-nilai dasar kehidupan. Individu saling menyetujui kontrak sosial. Orientasi penalaran moral pada tahap ini berupa upaya memaksimalkan kesejahteraan masyarakat, menghargai kemauan golongan mayoritas, namun juga menjaga hak-hak minoritas. Apabila undang-undang dan aturan yang ada dianggap individu tidak lagi sesuai, misalnya bertentangan dengan hak-hak kemanusiaan, maka penalar moral pada tahap kelima ini dapat melakukan kritik dan mengusahakan perubahan, serta mengembangkan cara untuk mengatasinya. Tahap kelima ini memiliki sifat utilitarianism rational, yaitu suatu keyakinan bahwa tugas dan kewajiban harus didasarkan pada tercapainya kebahagiaan bagi sebagian 
besar umat manusia. Di sini perhatian orang sudah sampai pada kesejahteraan bersama, tidak lagi condong pada individualisme sempit. Meski sebenarnya kata hati sudah mulai bicara, namun pernilaian-pernilaiannya masih belum timbul dari kata hati yang sudah benar-benar terinternalisiasi. Pada tahap ini anak masih mau diatur secara ketat oleh hukum-hukum umum yang lebih tinggi. Oleh karena itu perwujudannya dalam banyak hal sering nampak dalam sikapnya yang radikal dan kaku.

\section{Tahap 6: Prinsip Etika Universal (Universal ethical principles)}

Tahap ini merupakan penalaranan moral yang paling tinggi. Orang sudah mendasarkan pilihan-pilihan moral pada suara hati nuraninya sendiri. Di sini moralitas individu sudah from within, tidak lagi from outside. Hak, baik-buruk, ditentukan oleh keputusan suara batin, sesuai dengan prinsip-prinsip etis yang dipilih sendiri, dan mengacu pada konprehensivitas, universalitas, dan konsistensi logis. Pada tahap ini seseorang telah mampu melakukan tingkah laku tingkah laku moral yang dikemudikan oleh tanggung jawab batin sendiri. Prinsip-prinsip yang diyakini bersifat abstrak dan etis, bukan lagi peraturan moral formal. Pada intinya prinsip-prinsip universal keadilan, resiprositas, persamaan hak asasi manusia, dan rasa hormat seseorang akan hak-hak pribadi telah terinternalisasi dengan baik. Tahap keenam ini dapat dikatakan sebagai prinsip etis universal. Prinsip-prinsip yang diterima oleh orang yang berada pada tahap ini bukan disebabkan oleh persetujuan sosial, tetapi prinsip-prinsip tersebut berasal dari ide dasar keadilan, yaitu persamaan hak-hak asasi manusia dan penghargaan terhadap martabat kemanusiaan. Orang di tahap ini sudah dapat membuat keputusan moral secara otonom.

\section{Jenis-Jenis Perilaku Prososial}

Sebetulnya terdapat banyak jenis perilaku prososial dalam kehidupan sehari-hari. Menolong misalnya, yaitu aktivitas individu atau kelompok untuk membantu orang lain dengan 
cara meringankan beban penderitaan dan kesukaran fisik atau psikologi orang yang dibantu. Menolong dilakukan dengan kerelaan hati, yang dipikirkan subjek hanyalah bagaimana orang yang ditolong dapat menyelesaikan permasalahan yang sedang dihadapi. Aktivitas demikian tidak hanya bermanfaat bagi yang dibantu, namun sebenarnya juga bagi yang membantu. Bagi yang dibantu, masalahnya dapat terselesaikan, atau setidaknya dapat terkurangi bebannya. Adapaun bagi penolong, terdapat semacam kepuasan batin dapat membantu orang lain keluar dari persoalan yang melilitnya.

Jenis lain dari perilaku prososial adalah berbagi. Berbagi ini dapat dalam bentuk yang kasat mata, seperti uang, barang, dan berbagai jenis bantuan fisik lainnya, sampai yang berwujud non fisik, yaitu berbagi rasa. Dilihat dari perspektif ini, tinggi rendahnya perilaku prososial dapat dilihat dari besar kecilnya kesedian orang untuk berbagi dari apa yang dimiliki, untuk orang lain yang lebih membutuhkan. Adapapun berbagai rasa bentuknya dapat berupa kesediaan individu untuk ikut merasakan apa yang dirasakan orang lain, mendengarkan keluhan orang lain. Dengan rasa empati yang tinggi orang dapat menggunakan perasaannya seolah-oleh berada dalam situasi orang lain. Individu didorong oleh emosinya seperti ikut mengambil bagian dalam "kehidupan" orang lain. Berbagai aktivitas demikian tentu sangat dirasakan manfaatnya bagi kedua belah pihak, penolong dan yang ditolong.

Kerjasama merupakan jenis berikutnya dari perilaku prososial. Kerjasama tidak lain adalah aktivitas melakukan pekerjaan, kegiatan atau usaha oleh beberapa orang (badan, lembaga) secara bersama-sama berdasarkan kesepakatan untuk mencapai tujuan bersama pula. Kerjasama ini dapat dilakukan pada level individu maupun kelompok. Aktivitas demikian memungkinkan semua pihak yang terkait dapat saling memperkuat daya kemampuan, sehingga menghasilkan kinerja yang lebih optimal. Di era modern, aktivitas pekerjaan yang stand alone cenderung digantikan oleh berbagai bentuk kerjasama atau aliansi. Sinergi antar pribadi maupun kelompok, yang dilakukan dengan membangun kerjasama harmonis, akan melahirkan berbagai kemajuan yang 
mungkin tidak terbayangkan sebelumnya: in harmonia progressio.

Jenis berikutnya dari perilaku prososial adalah menyumbang. Menyumbang, yang dalam bahasa Indonesia berarti berlaku murah hati kepada orang lain, ikut menyokong dengan tenaga dan pikiran, memberikan sesuatu kepada orang yang sedang tertimpa musibah, merupakan perilaku prososial yang sering terlihat dalam kehidupan masyarakat. Pada masyarakat Indonesia yang dikenal guyup, menyumbang seolah menjadi ritual wajib. Bahkan, dalalam budaya tertentu di republik ini, menyumbang diyakini sebagai upaya tolak balak, yaitu laku "spiritual" yang dapat menjauhkan pelakunya dari marabahaya. Dalam bahasa Agama, menyumbang menjadi salah satu tolok ukur kesalehan sosial pelaku.

Memperhatikan kesejahteraan orang lain juga termasuk jenis dari perilaku prososial. Hasrat untuk menolong orang lain tanpa memikirkan kepentingan sendiri merupakan ciri orang yang perilaku prososialnya tinggi. Sebaliknya, semakin tidak peduli seseorang terhadap kesejahteraan orang lain menunjukkan rendahnya perilaku prososial yang bersangkutan. Pada masyarakat urban yang kosmopolit, seperti yang terlihat di kota-kota besar, nampak menipisnya kepedulian orang terhadap kesejahteraan orang lain. Pada masyarakat individualistis seperti ini kesenjangan antara kaya-miskin biasanya akan tampat sangat menyolok. Pada gilirannya, jika kesenjangan sosial-ekonomi sudah sedemikian parah, tinggal tunggu waktu munculnya berbagai persoalan sosial, yang dalam dosis tertentu akan dapat menjelma menjadi kerusuhan sosial.

\section{Tahap-tahap dalam Perilaku Prososial}

Rupaya perilaku prososial tidak terjadi begitu saja. Jika terdapat seseorang yang berbaik hati menolong orang lain, ternyata didahului oleh adanya proses psikologis sebelum sampai kepada keputusan menolong. Baron dan Branscombe (2012) mengemukakan bahwa respon individu dalam situasi 
darurat meliputi lima langkah penting yang dapat menimbulkan perilaku prososial atau tindakan berdiam diri saja. Tahap-tahap tesebut meliputi:

\section{Tahap perhatian, subjek menyadari adanya keadaan darurat}

Subjek mulai menyadari ada sesuatu yang tidak biasa terjadi. Keadaan darurat jelas merupakan sesuatu yang terjadi tiba-tiba. Oleh karena situasi demikian terjadi begitu mendadak, secara tiba-tiba, sudah barang tentu orang tidak memiliki persiapan khusus untuk mengantisipasi kejadiannya, dan belum merencanakan bagaimana cara terbaik untuk menanggapi. Pada tahap ini sering terjadi gangguan, sehingga subjek tidak memperhatikan bahwa telah terjadi keadaan darurat, misalnya oleh karena subjek sibuk, tergesa-gesa, suntuk dengan persoalan hidupnya sendiri, atau terdesak kepentingan lain dan sebagainya. Gangguan-gangguan demikian dapat menjadi penyebab ketidakmunculan perilaku prososial dalam keadaan darurat.

\section{Menginterpretasikan keadaan sebagai keadaan darurat}

Kejelasan informasi penting pada tahap ini. Sebab meskipun kita telah memperhatikan peristiwa yang terjadi, orang tidak jarang hanya memiliki informasi yang terbatas dan tidak lengkap terhadap apa yang sebenarnya terjadi. Ketidak lengkapan informasi ini menyebabkan subjek gagal menginterpretasi kejadian sebagai keadaan darurat yang memerlukan pertolongan. Manakala individu tidak memandang suatu peristiwa sebagai keadaan yang diinterpretasi sebagai "darurat" sehingga perlu ditolong, kemungkinan besar perilaku prososial tidak akan muncul. Namun sebaliknya, apabila pemerhati menginterpretasi suatu kejadian sebagai sesuatu yang darurat, membutuhkan pertolongan, kemungkinan besar subjek akan menginterpretasikan kejadian itu sebagai korban yang memerlukan pertolongan, sehingga yang bersangkutan tergerak untuk membantu. 


\section{Mengasumsikan bahwa merupakan tanggung jawabnya untuk menolong}

Manakala individu memberi perhatian kepada beberapa kejadian di lapangan dan yang bersangkutan menginterpretasikannya sebagai suatu situasi darurat, perilaku prososial baru akan dilakukan hanya jika orang tersebut mengambil tanggung jawab untuk menolong. Ini berarti apabila pemerhati tidak merasa bertanggung jawab, maka korban cenderung akan dibiarkan, tanpa mendapatkan pertolongan. Dalam beberapa kasus, tanggung jawab untuk menolong sedemikian jelas. Sementara pada kasus lain tidak. Misalnya petugas pemadam kebakaran, sudah menjadi tanggung jawabnya untuk membantu jika terjadi kebakaran. Mereka akan berada di garis depan untuk berusaha memadamkan api. Polisi juga demikian, jika terjadi kecelakaan lalu lintas di dekatnya, polisi tentu merasa bertanggung jawab untuk menolong karena itu sudah menjadi tugasnya. Adapun para pengguna jalan, yang juga mengetahui ada kecelakaan, tidak jarang terus berlalu memacu kendaraanya kearah tujuan semula, karena melihat sudah apa polisi yang bertanggung jawab menolong korban. Pengguna jalan seolah merasa "boleh" melepas tanggung jawab membantu, karena sudah ada polisi, yang berwajib.

\section{Mengetahui dan terampil mengenai apa yang harus dilakukan}

Pada kenyataannya, meskipun individu sudah memperhatikan peristiwa yang terjadi, menginterpretasikannya sebagai keadaan darurat, dan merasa bertanggung jawab untuk membantu, namun belum tentu dia akan dapat melakukan sesuatu yang berarti, kecuali jika yang bersangkutan benar-benar mengetahui dan memiliki cukup keterampilan bagaimana cara menolongnya. Jika subjek tidak mengetahui bagaimana cara memberikan pertolongan yang semestinya, dan tidak cukup memiliki kapasitas dan keterampilan yang diperlukan untuk membantunya, ada kecenderungan yang bersangkutan hanya akan diam saja, tidak tergerak untuk memberikan pertolongan. Ada beberapa 
kasus, yang memang tidak memerlukan pengetahuan dan keterampilan khusus untuk menolong. Misalnya ketika ada ibu-ibu yang jatuh terpeleset karena lantai mall yang licin. Dapat dipastikan, hampir semua pengunjung yang berada di dekat ibu jatuh akan membantunya berdiri. Berbeda dengan kasus kecelakanan ketika ada yang tenggelam di kolam renang, hanya mereka yang bisa berenang dengan baik yang tergerak untuk menolong. Atau di saat ada mobil mogok di pinggir jalan, tidak semua pengguna jalan tergerak untuk membantu. Hanya mereka yang mengerti mesin dan memiliki keterampilan memadai untuk memperbaiki mobil saja yang cenderung untuk berhenti dan menolongnya. Ini beraarti manakala kejadian darurat memerlukan keterampilan khusus untuk membantunya, biasanya hanya sedikit pemerhati yang akan tergerak menolong.

\section{Mengambil keputusan untuk menolong}

Tahap pengambilan keputusan merupakan tahap yang paling krusial dalam perilaku prososial. Meskipun individu telah melaui semua tahapan di atas dan bahkan telah mencapai tahap merasa bertanggung jawab untuk memberikan pertolongan pada korban, serta memiliki keterampilan memadai yang diperlukan untuk dapat menolong, masih pula terdapat kemungkinan yang bersangkutan memutuskan untuk tidak memberi pertolongan. Berbagai kekhawatiran yang muncul dapat menjadi penghambat terjadinya pemberian pertolongan. Misalnya, di saat subjek akan menolong korban tenggelam di pantai di mana resiko ikut tenggelam juga besar, ada kemungkinan teman atau pemerhati yang merasa bertanggung jawab dan dapat berenang dengan baik sekalipun akan berpikir ulang untuk menolong korban yang terseret ombak ke laut lepas, dengan gelombang yang ganas. Tahap akhir dari perilaku psososial ini, yaitu keputusan untuk menolong, dapat dihambat oleh rasa takut, sering kali memang merupakan rasa takut yang nyata, bukan sekedar kekhawatiran, terhadap adanya konsekuensi negatif yang potensial akan dihadapi oleh pemberi bantuan. Penolong akan melakukan semacam kalkulasi 
matematis menyangkut peluang positif dan resiko negatif yang bakal terjadi jika ia menolongnya. Jika menurut perhitungan subjek resiko negatifnya terlalu besar sering kali dorongan munculnya perilaku prososial dapat terhenti.

\section{Teori-Teori Perilaku Prososial}

Sarwono \& Meinarno (2009) menyatakan, terdapat lima teori yang menjelaskan tentang perilaku prososial, yaitu teori evolusi, belajar, empati, perkembangan kognisi sosial dan norma sosial. Berikut akan dijelaskan secara ringkas masing-masing teori dimaksud:

\section{Teori Evolusi}

Teori ini beranggapan bahwa perilaku prososial ini demi survival, yaitu mempertahankan jenis dalam evolusi. Dalam perilaku prososial, kecenderungan untuk menolong orang lain, mempunyai nilai untuk menjaga kelangsungan hidup. Oleh karena inti dari kehidupan adalah keberlangsungan hidup gen, maka perilaku prososial didorong oleh gen yang ada dalam diri untuk memaksimalkan kesempatan keberlangsungannya agar tetap lestari. Teori evolusi mengutamakan argumen genetika dalam menjelaskan perilaku prososial.

\section{Perlindungan kerabat}

Sudah menjadi naluri setiap orang tua untuk mengutamakan kesejahteraan anak dibandingkan dengan kepentingan dirinya sendiri. Dorongan demikian menyebabkan gen mempunyai peluang lebih besar untuk bertahan dan lestari. Secara biologis, adanya kedekatan genetik ini membuat manusia secara alami terprogram untuk lebih menolong orang yang masih tergolong kerabatnya sendiri. Seleksi keluarga merupakan konsep evolusi yang memerikan penegasan bahwa orang akan cenderung membantu orang lain yang masih terkait dengan mereka, secara keluarga. Beberapa penelitian psikologis menunjukkan, orang 


\section{Khoiruddin Bashori}

merasa lebih protektif dan terhubung dengan mereka yang terkait secara keluarga - makin dekat hubungan tersebut, makin kuat pula perasaan itu. Ini berarti, dalam kondisi yang sama, seseorang kecenderungan ingin membantu saudara kandung melebihi keinginannya untuk membantu saudara sepupu, apalagi orang lain yang tidak ada hubungan kekerabatan sama sekali. Menurut teori evolusi, hal demikian terjadi karena seseorang ingin gennya bertahan untuk generasi mendatang. Individu membantu keluarganya karena dia menganggap keluarga memiliki beberapa gen yang sama dengan dirinya sehingga, menurut perspektif teori evolusi, seseorang cenderung akan memilih orang-orang yang paling erat kaitannya dengan dirinya untuk dibantu.

\section{Timbal balik biologis}

Salah satu motivasi yang mendorong seseorang untuk menolong adalah adanya anggapan mekanisme timbal balik. Terdapat semacam asumsi bahwa kelak orang yang ditolong akan menolongnya kembali sebagai balasan. Sementara jika ia tidak menolong suatu saat dirinya juga tidak akan mendapat pertolongan. Perasaan seperti itulah yang menjadi motivasi individu untuk menolong orang lain. Motivasi ini tentu akan semakin kuat apabila yang ditolongnya masih tergolong kerabatnya sendiri. Dalam masyarakat beragama, keyakinan demikian sering disebut sebagai hukum karma. Kebaikan akan berbalas kebaikan, keburukan akan mendatangkan keburukan pula dalam kehidupan. Pada komunitaas dengan religiusitas yang tinggi, efek resiprokal ini diyakini tidak hanya terbatas pada orang yang dibantu. Balasan kebaikan yang telah dilakukan ketika membantu orang lain akan berbalas dengan kebaikan, bantuan, yang mungkin saja dilakukan oleh orang lain lagi, yang bukan seseorang yang telah dibantunya itu. Ini sebabnya, orang dengan penghayatan religius tinggi cenderung lebih mudah membantu orang lain. 
Teori Belajar

\section{Teori belajar sosial}

Tingkah laku manusia dijelaskan sebagai hasil proses belajar dalam interaksinya dengan lingkungan, utamanya dengan orang orang-orang penting terdekatnya di rumah. Sebagian besar perilaku sosial anak dipelajari sejak kecil dari orang tuanya. Sosialisasi merupakan proses pembentukan perilaku prososial seseorang agar sesuai dengan harapan dan standar etik budaya masyarakatnya. Di sinilah pentingnya orang tua tidak saja untuk mengajarkan nilai-nilai prososial akan tetapi sekaligus dapat menjadi model, menjadi teladan perilaku sosial bagi keluarganya. Pada masyarakat timur yang bercirikan gotong-royong, perilaku prososial merupakan kesalehan sosial yang terpuji. Nilai demikian, dari waktu ke waktu, terinternalisasi dalam diri individu. Oleh karenanya, menurut teori belajar, seseorang dapat merasa lebih baik, merasa menjadi orang baik, setelah memberikan pertolongan. Atau dengan kata lain, seseorang menolong untuk menghindari perasaan bersalah atau malu jika tidak menolong. Ada semacam perasaan asosial bila tidak melakukan tindakan prososial terhadap mereka yang perlu dibantu. Internalisasi nilai-nilai prososial akan semakin kuat bila aktivitas prososial dimaksud kemudian mendapatkan pengukuh dari lingkungannya.

\section{Teori pertukaran sosial.}

Terjadinya interaksi sosial bergantung pada untung dan rugi yang diperoleh. Pandangan transaksional ini tidak harus berujud materi, dapat pula bersifat non materi, seperti perhatian, pujian, penghargaan dan sejenisnya. Tingkah laku menolong juga dapat dipandang semata-mata untuk menutupi kepentingan pribadi seseorang. Menurut teori ini, perilaku prososial bersifat transaksional. Perhitungan untuk rugi menjadi pertimbangan ketika seseorang akan mengeksekusi perilaku prososial. Jika peluang mendapatkan keuntungan dengan perilaku menolong orang lain 


\section{Khoiruddin Bashori}

terasa lebih besar bila dibandingkan dengan kerugiannya, maka individu akan cenderung membantu. Namun jika sebaliknya yang diperkirakan akan terjadi, misalnya dengan tindakan membantu justru akan menimbulkan kerugian bagi yang bersangkutan maka akan menurunkan motivasi subjek untuk menolong. Dalam hal ini, yang dimaksudkan dengan keuntungan jika hasil yang akan diperoleh lebih besar dari usaha yang dikeluarkan, sebaliknya yang dimaksud dengan kerugian manakala hasil yang akan didapat lebih kecil dari usaha yang dikeluarkannya. Berdasarkan prinsip sosial ekonomi ini maka setiap perilaku sosial yang akan dipilih subjek pada dasarnya dilaksanakan dengan menggunakan strategi minimal, meminimalkan usaha dan memaksimalkan hasil agar di peroleh keuntungan, baik fisik maupun psikologis, yang sebesar-besarnya.

\section{Teori Empati}

Seseorang dapat merasakan apa yang dialami orang lain. Manusia dilengkapi dengan kemampuan kognitif dan afektif untuk mampu memahami apa yang dipikirkan dan dirasakan orang lain beserta alasannya, mengapa mereka merasa demikian terhadap peristiwa tertentu yang dialami. Teori ini meyakini bahwa egoisme dan simpati berfungsi bersama dalam perilaku menolong. Dari segi egoisme, perilaku menolong dapat mengurangi ketegangan diri sendiri, sedangkan dari segi simpati perilaku menolong dapat mengurangi penderitaan orang lain. Gabungan dari keduanya dapat menjadi empati, yaitu ikut merasakan penderitaan orang lain sebagai penderitaannya sendiri (Sarwono, 2006).

\section{Hipotesis empati-altruisme}

Perhatian empatik yang dirasakan seseorang terhadap penderitaan orang lain akan menghasilkan motivasi bagi individu untuk mengurangi penderitaan orang tersebut. Seseorang lebih cenderung untuk membantu orang lain jika mereka merasa empati terhadap penderita. Sebagai contoh, jika ses- 
Menyemai Perilaku Prososial di Sekolah

eorang melihat orang lain tiba-tiba kesakitan terkena serangan jantung, mungkin pemerhati membayangkan bagaimana rasanya berada dalam situasi itu. Dengan membayangkan apa yang dirasakan orang lain, pemerhati terdorong untuk membantu penderita. Dengan demikian, empati dapat menyebabkan altruisme. Menurut hipotesis empati-altruisme, seseorang paling mungkin membantu jika dirinya merasa sangat berempati dan situasi tersebut sulit untuk dilupakan. Maksudnya adalah jika misalnya pemerhati dapat dengan mudah melupakan bahwa penderika terkena serangan jantung, oleh karena yang bersangkutan kurang memahami ciri-ciri penderita yang mengalami serangan jantung, maka pemerti lebih cenderung untuk tidak menolong karena dianggapnya itu adalah sakit biasa. Akan tapi jika pemerhati merasa sangat berempati dan penderitaan subjek sulit untuk dilupakan, maka pemerhati lebih cenderung untuk segera membatu penderita.

\section{Model mengurangi perasaan negatif}

Orang menolong untuk mengurangi perasaan negatif akibat melihat penderitaan orang lain. Seseorang berada dalam suasana hati negatif sebelum melihat orang yang sedang kesusahan dan dengan menolong diharapkan ia dapat mengurangi perasaan negatifnya tersebut. Model ini mengasumsikan bahwa dengan menolong orang lain, individu dapat mengurangi perasaan negatif, tidak enak, yang dirasakannya. Dengan menolong yang bersangkutan merasa plong, telah melakukan sesusai yang secara sosial dipandang baik. Apabila individu memutuskan untuk tidak membantu, karena alasan-alasan tertentu, maka yang bersangkutan akan terus merasa tidak enak, semacam dihantui oleh perasaan bersalah.

\section{Hipotesis kesenangan empatik}

Seseorang akan menolong manakala ia memperkirakan dapat ikut merasakan kebahagiaan orang yang akan ditolong atas pertolongan yang diberikannya. Seseorang menolong karena 
percaya bahwa pertolongannya akan memberikan hasil yang positif bagi penerima. Bagi orang yang dibantu, perasaan senang akan hadir karena persoalan yang sedang dihadapi mendapatkan solusi. Perasaan demikian ternyata tidak hanya dialami oleh orang yang ditolong, akan tetapi juga dapat dirasakan oleh menereka yang menolongnya. Ada semacam kesenangan empatik, subjek dapat ikut merasakan kesenangan orang lain yang dibantu.

\section{Teori Perkembangan Kognisi Sosial}

Dalam merespon suatu situasi darurat, yaitu situasi yang membutuhkan pertolongan, tentu diperlukan sejumlah informasi yang harus diproses dengan cepat sebelum seseorang memutuskan untuk memberikan pertolongan. Ketersediaan kelengkapan informasi yang berkaitan dengan situasi sosial yang tengah terjadi, memudahkan orang tergerak untuk membantu. Blow up media yang sedemikian masif ketika terjadi bencana tsunami di Aceh, dan gempa bumi di Jogjakarta beberapa tahun yang lalu, menjadi pengalaman yang menarik betapa peran media dalam menghadirkan perkembangan situasi aktual di daerah bencana telah dapat menggerakkan energi sosial masyarakat untuk berbondong-bodong membantu, tidak sekadar secara finansial akan tetapi juga secara langsung menerjunkan diri menjadi relawan. Banyak petani sederhana dari luar daerah datang ke Bantul Yogyakarta, dengan menaiki truk-truk proyek sambil membawa kelengkapan masak sendiri, mereka menyumbangkan tenaga, karena hanya itu yang mereka punya, membantu saudara-saudaranya yang sedang menjadi korban gempa untuk bersih-bersih lingkungan dan kembali membangun rumah yang porak poranda karena gempa.

\section{Teori Norma Sosial}

Norma sosial merupakan standar bersama suatu komunitas yang menyangkut apa yang diangap perilaku yang pantas dalam situasi-situasi terentu. Norma sosial tidak hanya penting untuk urusan kepatuhan dan ketaatan, akan tetapi juga penting 
bagi perkembangan perilaku prososial.

\section{Norma timbal-balik}

Dalam kehidupan bermasyarakat terdapat prinsip balas budi. Jika seseorang pernah ditolong orang, sudah sepantasnya yang bersangkutan gantian menolong orang lain. Perilaku menolong ini tidak harus ditujukan kepada orang yang pernah menolongnya, menolong dapat dilakukan kepada siapa saja yang dirasa memerlukan bantuan. Dalam perspektif ini, norma timbal balik inilah yang menggerakkan orang untuk membantu orang lain. Perlu ditegaskan di sini bahwa norma demikian bersifat universal, dikenal sebagai moral code di hampir dalam setiap kebudayaan. Beberapa penelitian menunjukkan, bantuan dalam jumlah yang lebih besar cenderung lebih sering dibalas bila dibandingkan dengan bantuan yang lebih kecil. Meskipun besar kecilnya bantuan bersifat relatif. Milyarder yang membantu puluhan juta pada yayasan kemanusiaan mungkin terasa kecil bila dibandingkan dengan bantuan tenaga yang dilakukan oleh orang kecil ketika kerja bakti berhari-hari membangun rumah tetangganya di sebuah perkampungan miskin. Pandangan orang tentang motif penolong juga berpengaruh dalam hal ini. Upaya membalas pertolongan orang lain lebih mungkin terjadi bila bantuan dipersepsi sebagai sesuatu yang diberikan secara sengaja dan sukarela.

\section{Norma tanggung jawab sosial}

Dalam sebuah hubungan sosial, seseorang akan berbuat seimbang antara memberi dan menerima. Norma tanggung jawab sosial mendorong individu untuk memberikan pertolongan kepada orang yang membutuhkan bantuan tanpa mengharapkan balasan di masa datang. Dengan demikian rasa tanggung jawab sosiallah yang menggerakkan orang untuk membantu saudaranya yang memerlukan, bukan karena berharap akan ganti mendapatkan bantuan di kemudian hari. Dalam konteks ini individu merasa ikut bertanggung jawab atas kesejahteran orang 
lain. Teori ini mengatakan, kita wajib menolong orang lain tanpa mengharapkan balasan apapun dimasa depan, sebagai ungkapan rasa tanggung jawab dalam bersosialisasi dengan masyarakat. Norma ini menentukan bahwa kita seharusnya membantu orang lain sebab aturan agama dan moral di masyarakat menekankan kewajiban untuk saling bantu-membantu dan tolong-menolong (Sears, Fredman \& Peplau, 1985).

\section{Faktor-Faktor yang Mempengaruhi Perilaku Prososial}

Menurut Sarwono \& Meinarno (2009) terdapat dua faktor yang mempengaruhi perilaku prososial, yaitu faktor situasional dan faktor dalam diri. Kedua faktor tersebut dapat dijelaskan sebagai berikut:

\section{Pengaruh Faktor Situasional}

\section{Bystander}

Ketika seseorang dihadapkan pada situasi darurat, orangorang yang berada di sekitar kejadian mempunyai peran sangat besar dalam mempengaruhi keputusannya untuk menolong atau tidak. Manakala orang lain di sekitar subjek banyak yang tergerak untuk membantu, itu akan sangat memudahkan bagi yang bersangkutan untuk ikut pula membantu. Begitu pula sebaliknya, jika orang di sekitarnya diam, ada semacam kelembaman pada diri subjek untuk membantu. Bila terjadi kecelakaan lalu lintas, kemudian banyak orang yang berkerumun membantu, pemerhati yang sedang berlalu cenderung untuk ikut berhenti, menyaksikan dan membantu memberikan pertolongan kepada korban.

\section{Daya Tarik}

Seseorang yang mengevaluasi korban secara positif, memiliki daya tarik, cenderung menyebabkan yang bersangkutan memiliki kesediaan untuk memberikan bantuan kepada korban. 
Efek ini terjadi dalam berbagai bentuk. Wanita cantik misalnya, akan lebih banyak menerima bantuan dari orang lain bila dibandingkan dengan orang yang kurang menarik. Orang kaya lebih sering mendapatkan kemudahan dari orang lain dibanding orang miskin. Daya tarik ini dapat berupa penampilan fisik ganteng dan cantik, kekayaan, status sosial, jabatan dan sejenisnya. Sejumlah penelitian menunjukan, orang-orang dengan daya tarik lebih ini cenderung mendapatkan perlakuan yang lebih baik dari orang lain, bila dibandingkan dengan mereka kurang memiliki daya tarik.

\section{Atribusi terhadap korban}

Adanya asumsi bahwa ketidakberuntungan korban adalah di luar kendali korban menjadi motivasi seseorang untuk memberikan bantuan pada orang lain. Anggapan pemerhati bahwa musibah yang terjadi adalah bencana alam yang tidak direncanakan akan lebih mendorong orang untuk membantu. Hal ini dapat dilihat pada kasus-kasus korban bencana alam, banjir bandang, tanah longsor atau letusan gunung berapi. Atribusi terhadap korban yang memang terlihat sangat membutuhkan pertolongan menggerakkan pemerhati untuk terjun membantu. Atribusi demikian dapat diperkuat oleh media sosial maupun elektronik. Kasus gempa dan gelombang raksasa tsunami Aceh 26 Desember 2004 yang mendapat liputan media sedemikian masif mampu menggerakkan seluruh komponen bangsa, bahkan komunitas internasional, untuk berduyun-duyun datang ke Aceh memberikan bantuan yang sangat diperlukan.

\section{Ada model}

Modeling diketahui memiliki peran yang sangat kuat untuk mendorong orang memunculkan perilaku prososial. Keteladanan memberikan pengaruh yang lebih kuat daripada sekedar nasehat dengan kata-kata. Seseorang akan terdorong untuk memberikan pertolongan kepada orang lain manakala terdapat model yang melakukan tingkah laku menolong. Jika dalam komunitas 


\section{Khoiruddin Bashori}

terdapat cukup model dengan perilaku prososial tinggi, lebih mudah bagi anggota komunitas tersebut untuk melakukan hal yang sama dengan sang model. Dalam teori belajar sosial Bandura, orang cukup dapat mempelajari dan menirukan perilaku model hanya dengan melihat. Proses demikian disebut Bandura sebagai observational learning. Proses belajar ini terutama kuat terjadi di usia kanak-kanak. Agar observational learning terjadi anak harus mencurahkan perhatian kepada perilaku model, mengingat dengan seksama perilaku yang diamatinya itu, mancoba mereplikasi perilaku dimaksud, dan dengan niat kuat terus mewujudkannya. Jika model mendapatkan "hadiah" dari tindakannya, dan semakin subjek kagum dan hormat kepada model, maka semakin besar kemungkinan subjek untuk mereplikasi perilaku prososial model.

\section{Desakan waktu}

Ketersediaan cukup waktu merupakan faktor penting dalam mewujudkan perilaku prososial. Orang yang sibuk dan tergesa-gesa karena memiliki kepentingan mendesak cenderung tidak menolong. Di sisi lain, orang dengan waktu luang lebih besar cenderung untuk memberikan pertolongan kepada yang memerlukannya. Keterbatasan waktu ini pula yang sering kali menjadi penyebab mengapa di kota-kota besar perilaku prososial cenderung lebih rendah dibandingkan dengan masyarakat tradisional di pedesaan yang kehidupannya tidak terlalu diburu oleh waktu. Ketersediaan cukup waktu membuat masyarakat desa lebih mungkin melakukan berbagai aktivtias sosial yang dapat memperkuat tradisi gotong royong, saling menolong.

\section{Sifat kebutuhan korban}

Kesediaan untuk menolong dipengaruhi pula oleh kejelasan bahwa korban benar-benar membutuhkan pertolongan, korban memang layak mendapatkan bantuan yang dibutuhkan. Keadaan korban yang benar-benar membutuhkan pertolongan mendorong orang lain untuk membantu. Di saat orang lain 
Menyemai Perilaku Prososial di Sekolah

melihat korban nampak tidak berdaya, semakin kuat dorongan bagi yang bersangkutan untuk terdorong membantu korban. Situasi seperti ini yang kemudian dimanfaatkan secara keliru oleh pengemis di kota-kota besar, dimanipulasi sedemikian rupa dengan berlagak kakinya buntung, mengenakan baju kumal, bahkan menggunakan anak-anak kecil dan bayi untuk menyedot belas kasihan pemerhati.

\section{Pengaruh Faktor dalam Diri}

\section{Suasana hati}

Sejumlah penelitian mengindikasikan pengaruh emosi positif dan emosi negatif terhadap kemunculan tingkah laku menolong. Subjek dengan suasana hati positif cenderung lebih mudah menolong orang lain bila dibandingkan dengan individu dengan suasana hati negatif. Suasana hati memang berubah-ubah, terkadang goog mood, namun di saat lain bad mood. Manakala subjek belum cukup matang secara emosi, maka suasana hatinya akan sangat mudah terpengaruh oleh hal-hal yang terjadi di luar dirinya. Orang semacam ini dikenal dengan istilah life form outside. Adapun individu yang relatif sudah mampu mentransformasikan diri menjadi life from within, dinamika batinnya lebih banyak di gerakkan oleh nilai-nilai dan keyakinan internal yang sudah mantap cenderung stabil suasana hatinya. Life from within karenanya menjadi penting karena begitu suasana hati berubah, kecenderungan orang untuk berperilaku prososial juga mengalami perubahan.

\section{Sifat}

Sifat atau karakteristik yang dimiliki seseorang diketahui dapatmempengaruhi kecenderungan menolong orang lain. Dalam masyarakat dikenal berbagai sebutan untuk mencirikan mereka yang peduli dan tidak peduli. Dermawan, murah hati, baik hati adalah sekelumit sebutan yang biasa disematkan kepada mereka yang memiliki paradigma kelimpahruahan. Orang-orang dengan 
sifat seperti ini akan dengan mudah mengulurkan bantuan kepada siapa saja yang memerlukan dukungannya. Namun ada pula pribadi-pribadi yang disifati masyarakat sebagai kikir, pelit, sulit dan semacamnya. Orang-orang dengn paradigma kelangkaan ini menganggap jika apa yang dimiliki adalah terbatas dan akan berkurang jika dibagi dengan orang lain.

\section{Jenis kelamin}

Sejumlah penelitian menunjukkan bahwa perempuan lebih banyak menerima pertolongan di bandingkan dengan lakilaki. Sementara laki-laki, dalam berbagai situasi, lebih banyak menolong bila dibandingkan dengan perempuan(Brigham,1991). Terdapat beragam argumen yang dikemukakan untuk menjelaskan kenyataan tersebut, salah satunya adalah peran jenis yang dipelajari dari kebudayaan. Perempuan diasosiasikan dengan hal-hal yang feminin sedang laki-laki maskulin: dikesankan perkasa, pahlawan, dan lugas. Dalam tradisi timur, laki-laki juga lebih dipersiapkan secara budaya untuk memiliki keterampilan yang diperlukan untuk melindungi dan menolong perempuan. Dalam perkembangannya, di era modern seperti sekarang ini, peran jenis tidak lagi kaku seperti pada periode-periode sebelumnya. Sekarang sudah jamak laki-laki mengerjakan tugas perempuan dan perempuan entah karena pilihan hidup atau dipaksa keadaan mampu melakukan tugas-tugas laki-laki. Lakilaki dan perempuan kini memiliki kesempatan yang sama untuk dapat mengembangkan perilaku prososial.

\section{Tempat tinggal}

Sudah menjadi rahasia umum, orang yang tinggal di pedesaan cenderung lebih penolong daripada mereka yang tinggal di daerah perkotaan. Suasana kota yang padat dan kompetitif, disadari atau tidak, teleh mempengaruhi pola hidup penghuninya. Di kota semangat kompetisi lebih menonjol dari kolaborasi, sementara di pedesaan hampir sepenuhnya kolaborasi. Itulah mengapa suasana gotong royong yang guyup lebih 
mudah ditemukan di pedesaan daripada di perkotaan. Di kota kecenderungan pola relasi transaksional sangat menonjol. Banyak hal dihargai dengan uang. Oleh karena itu menjadi orang miskin di kota lebih menderita dari miskin di desa. Data BPS menunjukkan terdapat sejumlah daerah dengan budaya "desa" yang masih guyup, meski angka kemiskinannya tinggi namun tingkat harapan hidup dan level kebahagiaan warganya relatif tinggi. Mereka bahu membahu menjalani kesulitan hidup bersamasama. Karena dipikul bersama, saling tolong menolong, maka persoalan yang beratpun terasa ringan.

\section{Pola asuh}

Perilaku prososial anak tidak datang dengan sendirinya, melainkan diperoleh dari proses belajar yang panjang. Proses belajar di sini tidak hanya yang dilakukan di bangku sekolah tetapi yang justru lebih penting adalah yang diperolehnya dari didikan orang tuanya. Sebagaimana yang telah diungkapkan oleh Hurlock (1988) bahwa pada masa kanak-kanak, orang tua merupakan sarana proses sosialisasi yang utama. Sosialisasi terjadi melalui perbuatan orang tua yang menunjukkan penerimaan, kehangatan, dan kasih sayang sebagai contoh dari wujud perilaku anak. Peran orang tua dalam mengasuh, membimbing, mendidik, mengawasi, memberi perhatian, dan menjadi contoh yang baik bagi anak akan berdampak pada pembentukan perilaku prososialnya. Pola asuh orang tua dalam keluarga berarti kebiasaan orang tua, ayah dan atau ibu, dalam memimpin, mengasuh, dan membimbing anak dalam keluarga secara konsisten dan persisten (Djamarah, 2014). Pola asuh demokratis secara signifikan memfasilitasi adanya kecenderungan anak untuk tumbuh menjadi seseorang yang mandiri dan mau menolong, bila dibandingkan dengan pola-pola asuh lainnya.

\section{Meningkatkan Perilaku Prososial}

Kita tentu sependapat, yang paling penting dari tema ini adalah bagaimana dapat menumbuh suburkan perilaku pro- 
sosial dari generasi ke generasi. Modernitas, seperti apapun keadaannya, tidak boleh membawa serta limbah peradaban yang menghambat kemunculan perilaku prososial. Perkembangan ICT yang luar biasa telah berhasil mendekatkan yang jauh, namun pada saat yang sama ternyata telah menjauhkan yang dekat. Terasa sekali sekarang ini jika terdapat kerumunan orang, hampir dapat dipastikan mereka asyik dengan gadget-nya masing-masing. Memang interaksi virtual meningkat pesat, namun di sisi lain diikuti dengan berkurangnya interaksi langsung antar pribadi yang dengannya perilaku prososial lebih mungkin ditumbuhkan. Berikut adan disajikan aneka ragam penelitian telah dilakukan oleh para ahli psikologi sosial untuk dapat meningkatkan kemungkinan terjadinya perilaku prososial dalam kehidupan.

Sejak diri anak perlu dibiasakan dengan nilai-nilai prososial. Urgensi pengasuhan yang dapat menumbuhkan perilaku prososial semakin meningkat di tengah kepungan faktor-faktor situasional yang sulit dikendalikan. Dengan kuatnya nilai-nilai internal anak yang dibawa dari keluarga diharapkan anak tidak terlalu tergantung pada situasi-situasi eksternal, dan lebih yakin dengan standar-standar internal perilakunya sendiri (Baron \& Byrne, 2000). Berbagai studi menunjukkan, anak akan memiliki kontrol internal yang baik jika dibesarkan dalam keluarga dengan orangtua yang penuh kehangatan dan cinta. Bukan dididik dengan hukuman-hukuman fisik yang keras. Terdapat pola interaksi yang krusial antara orangtua dan anak. Anak-anak yang altruistik ternyata dibesarkan oleh orang orantua yang juga altruistik. Oleh karena itu, orangtua perlu menjadi model yang baik bagi anak.

Sepanjang masa pertumbuhannya anak lebih banyak menghabiskan waktu dalam keluarga, bersama orangtua, dibandingkan dengan orang lain. Mereka akan mengcopy apa yang mereka lihat. Dengan demikian, yang harus dipastikan oleh orangtua adalah hadirnya sejumlah contoh perilaku bagi nilai-nailai yang hendak ditransformasikan. Praktekkan kontrol diri sesering mungkin. Beri kesempatan anak untuk belajar memutuskan sendiri apa yang dianggapnya baik. Sudah barang tentu belum semua kepu- 
tusan anak benar, seperti harapan orangtua. Di sinilah fungsi orangtua sebagai pembimbing. Berikan koreksi seperlunya tanpa mengganggu hubungan emosional yang memang harus dijaga terus kelekatannya. Karena itu orangtua perlu membuat aturan keluarga yang jelas. Anak memerlukan a sense of structure, yaitu perasaan tertata karena memiliki patokan etis yang tegas. Hanya saja pada saat hendak menyusun peraturan orangtua perlu mendialogkannya bersama anak dan seluruh anggota keluarga.

Konsistensi dari kedua orangtua sangat diperlukan dalam upaya internalisasi nilai-nilai perilaku prososial. Kedua orangtua harus sepakat mengenai apa yang penting dan diprioritaskan dalam pendidikan anak-anaknya. Konsistensi dalam penegakan aturan hendaknya terus dijaga dari waktu ke waktu. Perlu pula ditambahkan di sini, aturan yang disepakati oleh seluruh anggota keluarga dibuat sedemikian rupa agar mudah bagi anak untuk mengingat dan memahaminya. Bila suatu ketika anak melanggar aturan, harus dipastikan mereka menerima konsekuensinya. Meskipun demikian, orangtua tetap harus menjadi kedekatan hubungan dengan semua anggota. Kedekatan ini ditunjukan antara lain dengan kesedian mereka mendengarkan keluhan anak. Siapkan anak untuk dapat memasuki situasi-situasi baru, agar mudah beradaptasi. Ajari anak untuk menunggu. Bantu anak untuk belajar menunda pemenuhan beberapa kebutuhan yang tidak mendesak. Kemanpuan ini merupakan cikal bakal perkembangan kontrol diri. Biasakan sejak dini untuk berbagai, meskipun hanya berupa berbagi cerita, senyuman, lelucon, mainan, dan giliran bermain.

Baron dan Byrne (2000) menyarankan perlunya mengurangi ambiguitas lingkungan dan mengajarkan perilaku bertanggung jawab. Penelitian menunjukkan bahwa keengganan orang untuk menolong salah satunya karena ambiguitas situasi. Ketidak jelasan apa yang sebenarnya terjadi seringkali menyebabkan pemerhati gagal mengerti bahwa baru saja telah terjadi keadaan darurat yang memerlukan pertolongan. Oleh karena itu, lewat pendidikan dan pelatihan, anak perlu diajari misalnya dengan berbagai simulasi kedaruratan dan kebencanaan agar mereka 
lebih sensitif dan tidak takut salah dalam memberikan respons yang semestinya. Di sekolah anak perlu diberi kesempatan yang lebih luas untuk berinteraksi secara positif. Para pendukung perspektif sosialisasi rekan sebaya berpendapat bahwa hubungan sebaya memberikan kesempatan bagi anak untuk belajar dan berlatih keterampilan prososial. Interaksi kolaboratif dengan teman sebaya juga diyakini dapat memotivasi pengembangan keterampilan kognitif yang mendukung terbentuknya perilaku prososial.

Kedekatan hubungan guru dengan siswa juga memiliki peran penting dalam internalisasi nilai-nilai prososial. Kewibaan guru dan kedekatan hubungannya dengan siswa akan memperkuat referent power yang dimilikinya. Referent power adalah kekuatan yang diperoleh atas dasar kekaguman, keteladanan, kharisma dan kepribadian dari seorang figur. Adalah sangat luar biasa pengaruhnya bagi perkembangan perilaku prososial siswa manakala para guru di sekolah dapat memerankan diri sebagai model ideal bagi nilai-nilai prososial. Dalam konteks pembelajaran, model instruksional kooperatif dan kolaboratif terbukti lebih dapat menumbuhkan perilaku menolong. Dalam hal ini, diskusi aktif, pemecahan masalah, dan umpan balik elaboratif antar rekan sebaya yang berinteraksi satu sama lain dapat memfasilitasi berkembangnya keterampilan prososial. Hasil-hasil studi di lapangan juga menunjukkan, kegiatan pembelajaran kooperatif yang paling sukses dalam mensosialisasikan nilai-nilai prososial adalah yang disertai interdependensi positif di antara anggota kelompok, akuntabilitas individual, interaksi tatap muka langsung (face to facwe) antar siswa, dan belajar keterampilan sosial yang diperlukan untuk bekerja sama.

\section{Kesimpulan}

Perilaku prososial tidak lain adalah perilaku memberikan manfaat kepada orang lain dengan membantu meringankan beban fisik atau psikologinya, yang dilakukan secara sukarela. Bentuk dari perilaku prososial ini dapat beraneka ragam, mulai 
Menyemai Perilaku Prososial di Sekolah

dari menyumbang, mendampingi, memperhatikan kesejahteraan orang lain dengan berbagai langkah kedermawanan, mempererat persahabatan, kerjasama yang saling menguatkan, menolong korban, menyelamatkan orang lain tanpa diminta, sampai mengorbankan diri untuk orang lain. Perilaku prososial juga mencakup tindakan yang dilakukan untuk memberikan keuntungan bagi orang lain, seperti berbagi, menghibur, memuji prestasi orang lain untuk menyenangnan hatinya, sampai menolong orang lain dalam mencapai tujuannya.

Siswa ibarat pemikir yang dapat membangun dan menyusun dunia hidup serta arti mengenai sejumlah kategori melalui tahap-tahap tertentu. Dalam penelitian Kohlberg (1981) mengenai dilema moral yang disodorkan kepada anak, tampak terdapat pikiran dengan struktur kognitif tertentu. Setiap kali anak bereaksi terhadap suatu dilema moral, pastilah didasarkan pada suatu pola operasi mental yang tersusun secara struktural. Dan berkat struktur kognitif khasnya ini pula anak kemudian memilih logika internalnya sendiri yang berbeda dari logika orang dewasa. Adapun konsep 'tahap' adalah setiap konstruksi mental kognitif yang secara kualitatif bersifat khas. Terdapat suatu ukuran tahap yang tetap dan tak dapat dibalik yang harus dilewati setiap orang sepanjang rentang kehidupannya. Konsep kunci untuk memahami perkembangan moral adalah internalisasi, yaitu perubahan perkembangan perilaku yang pada mulanya dikendalikan secara eksternal menuju perilaku yang dikendalikan secara internal.

Baron dan Branscombe (2012) terdapat lima langkah penting yang dapat menimbulkan perilaku prososial ketika seseorang melihat keadaan darurat yang memerlukan pertolongan: (1) tahap perhatian, subjek menyadari adanya keadaan darurat, (2) menginterpretasikan keadaan sebagai keadaan darurat, (3) mengasumsikan bahwa merupakan tanggung jawabnya untuk menolong, (4) mengetahui dan terampil mengenai apa yang harus dilakukan, (5) mengambil keputusan untuk menolong. Tahap pengambilan keputusan merupakan tahap yang paling krusial dalam perilaku prososial. Tahap akhir dari perilaku psososial ini, 
yaitu keputusan untuk menolong, dapat dihambat oleh rasa takut berupa konsekuensi negatif yang potensial akan dihadapi oleh pemberi bantuan. Penolong akan melakukan semacam kalkulasi matematis menyangkut peluang positif dan resiko negatif yang bakal terjadi jika ia menolongnya. Jika menurut perhitungan subjek resiko negatifnya terlalu besar sering kali dorongan munculnya perilaku prososial dapat terhenti.

Sejak diri siswa perlu dibiasakan dengan nilai-nilai prososial. Urgensi pengasuhan yang dapat menumbuhkan perilaku prososial semakin meningkat di tengah kepungan faktor-faktor situasional yang sulit dikendalikan. Dengan kuatnya nilai-nilai internal anak yang dibawa siswa dari sekolah diharapkan anak tidak terlalu tergantung pada situasi-situasi eksternal, dan lebih yakin dengan standar-standar internal perilakunya sendiri. Siswa akan memiliki kontrol internal yang baik jika dibesarkan dalam lingkungan sekolah dengan guru yang penuh kehangatan dan cinta. Bukan dididik dengan hukuman-hukuman fisik yang keras. Terdapat pola interaksi yang krusial antara guru dan siswa. Siswa yang altruistik ternyata dibesarkan oleh orang guru yang juga altruistik. Oleh karena itu, guru perlu menjadi model yang baik bagi siswa-siswinya.

Baron dan Byrne (2000) menyarankan perlunya mengurangi ambiguitas lingkungan dan mengajarkan perilaku bertanggung jawab. Penelitian menunjukkan bahwa keengganan orang untuk menolong salah satunya karena ambiguitas situasi. Ketidak jelasan apa yang sebenarnya terjadi seringkali menyebabkan pemerhati gagal mengerti bahwa baru saja telah terjadi keadaan darurat yang memerlukan pertolongan. Oleh karena itu, lewat pendidikan dan pelatihan, siswa perlu diajari misalnya dengan berbagai simulasi kedaruratan dan kebencanaan agar mereka lebih sensitif dan tidak takut salah dalam memberikan respons yang semestinya. Di sekolah siswa perlu diberi kesempatan yang lebih luas untuk berinteraksi secara positif. Para pendukung perspektif sosialisasi rekan sebaya berpendapat bahwa hubungan sebaya memberikan kesempatan bagi siswa untuk belajar dan berlatih keterampilan prososial. Interaksi kolaboratif dengan 
Menyemai Perilaku Prososial di Sekolah

teman sebaya juga diyakini dapat memotivasi pengembangan keterampilan kognitif yang mendukung terbentuknya perilaku prososial.

Kedekatan hubungan guru dengan siswajuga memiliki peran penting dalam internalisasi nilai-nilai prososial. Kewibawaan guru dan kedekatan hubungannya dengan siswa akan memperkuat referent power yang dimilikinya. Referent power adalah kekuatan yang diperoleh atas dasar kekaguman, keteladanan, kharisma dan kepribadian dari seorang figur. Adalah sangat luar biasa pengaruhnya bagi perkembangan perilaku prososial siswa manakala para guru di sekolah dapat memerankan diri sebagai model ideal bagi nilai-nilai prososial. Dalam konteks pembelajaran, model instruksional kooperatif dan kolaboratif terbukti lebih dapat menumbuhkan perilaku menolong. Dalam hal ini, diskusi aktif, pemecahan masalah, dan umpan balik elaboratif antar rekan sebaya yang berinteraksi satu sama lain dapat memfasilitasi berkembangnya keterampilan prososial. Hasil-hasil studi di lapangan juga menunjukkan, kegiatan pembelajaran kooperatif yang paling sukses dalam mensosialisasikan nilai-nilai prososial adalah yang disertai interdependensi positif di antara anggota kelompok, akuntabilitas individual, interaksi tatap muka langsung (face to facwe) antar siswa, dan belajar keterampilan sosial yang diperlukan untuk bekerja sama. 


\section{BIBLIOGRAFI}

Baron, R.A. \& Byrne, D. (2000). Social Psychology (9th Edition). Boston: Allyn and Bacon.

Baron, R.A. \& Branscombe, N.R. (2012). Social Psychology (13th Edition). Boston: Pearson Education, Inc.

Brigham, J.C. (1991). Social Psychology. New York: Harpercollins Publisher.

Djamarah, S.B. (2014). Pola Asuh Orang Tua dan Komunikasi dalam Keluarga. Jakarta: Rineka Cipta.

Durkin, K. (1995). Developmental Social Psychology, From Infancy to old age. Cambrigde, Mass: Blackwell.

Faturochman. (2006). Pengantar psikologi Sosial. Yogyakarta: Pinus.

Hurlock. (1988). Perkembangan Anak 3. Jakarta: Erlangga.

Kohlberg, L. (1976). "Moral stages and moralization: The cognitivedevelopmental approach". In Lickona, T. Moral Development and Behavior: Theory, Research and Social Issues. Holt, NY: Rinehart and Winston.

Kohlberg, L. (1981). Essays on Moral Development, Vol. I: The Philosophy of Moral Development. San Francisco, CA: Harper \& Row.

Kompas. 27 November 2015.

Kurtines, W.M, Gerwitz, J.L. (1984). Morality, Moral Behavior, and Moral Development. New York: John Wiley \& Sons.

Passer, M. M., \& Smith, R. E. (2007). Psychology: The science of mind and behavior (3rd ed). New York: McGraw-Hill.

Sarwono, S.W. (2006). Teori-Teori Psikologi Sosial. Jakarta: Rajawali Pers.

Sarwono, S. W. \& Meinarno, E. A. (2009). Psikologi Sosial. Jakarta: Salemba Humanika.

Sears, D.O, Freedman, J. L., dan Peplau, L.A. (1991). Psikologi Sosial. Edisi Kelima. Jilid 1. Alih Bahasa: Michael Adryanto. Jakarta: Erlangga. 